\title{
Anesthesia Induction's Effect on Pediatric Surgery under Parental Accompany: A Comprehensive Meta-Analysis of Randomized Controlled Trials
}

\author{
Xin Liang1* ${ }^{*}$ Zijing Zhang2*, Zumei Gao ${ }^{3 *}$, Wenfang Deng1, Wenbin He1, Haiyuan Zhang4\# \\ ${ }^{1}$ Yangtze University Health Science Center, Jingzhou, China \\ ${ }^{2}$ The Second School of Clinical Medicine, Yangtze University Health Science Center, Jingzhou, China \\ ${ }^{3}$ The First School of Clinical Medicine, Yangtze University, Jingzhou, China \\ ${ }^{4}$ School of Basic Medical Sciences, Yangtze University Health Science Center, Jingzhou, China \\ Email: "hyzhang_88@163.com
}

How to cite this paper: Liang, X., Zhang, Z.J., Gao, Z.M., Deng, W.F., He, W.B. and Zhang, H.Y. (2019) Anesthesia Induction's Effect on Pediatric Surgery under Parental Accompany: A Comprehensive Meta-Analysis of Randomized Controlled Trials. Yangtze Medicine, 3, 50-63. https://doi.org/10.4236/ym.2019.31006

Received: November 25, 2018

Accepted: March 19, 2019

Published: March 22, 2019

Copyright $\odot 2019$ by author(s) and Scientific Research Publishing Inc. This work is licensed under the Creative Commons Attribution International License (CC BY 4.0).

http://creativecommons.org/licenses/by/4.0/

\begin{abstract}
Objective: To evaluate the effect of anesthesia induction under parental company for children receiving general anesthesia. Methods: The RCT results were collected on children's preoperative anxiety, anesthesia coordination, anesthesia and recovery agitation, postoperative pain and parental preoperative anxiety intervention with or without parental accompany using RevMan 5.3 software based on Chinese and English database. We searched Cochrane Library, Pubmed, Medline, EMbase, Sciencedirect, SpringerLink, China Biomedical, CNKI, Wanfang, Weipu and other databases, and included 15 articles (5 Chinese, 10 English) with 1390 samples size, containing 700 cases of control group and 690 cases of testing group. Results: Our results showed that parents' and children's anxiety level, the incidence of restlessness during anesthesia induction and wake-up period were reduced, while the anesthesia coordination was enhanced and the pain of children after wake-up was alleviated under parental accompany. Conclusion: The risk and cost-free intervention of parental accompany could be recommended as appropriate in hospitals for its contribution to children's surgery effect.
\end{abstract}

\section{Keywords}

Pediatric Surgery, Anesthesia Induction, Parent Accompany, Meta-Analysis

${ }^{\star}$ Authors contributed equally. 


\section{Introduction}

Children are prone to be anxious and afraid when required to take anesthesia induction alone in a strange environment [1]. Around $40 \%-60 \%$ children will suffer from preoperative anxiety disorders and an over-high level of preoperative anxiety which will lead to a difficulty in anesthesia induction and agitation during the recovery period [2]. Domestic studies [3] have pointed out that Parent-Present Induction of Anesthesia (PPIA) could alleviate nervous feelings of children, which is conducive to a smooth anesthesia and surgery as well as an accelerated postoperative recovery; therefore, it has been gradually adopted in a world range. However, the clinical adverse consequence remains unclear and there are different opinions about it. Related studies [4] [5] have shown that parents may provide undesirable assistance due to their tension and poor nursing knowledge. In recent years, a large number of studies tend to only focus on analysis and summary of children's physiological and psychological anxiety indicators, instead of deeply investigating the relevant outcome indicators, such as anesthesia coordination, postoperative pain, agitation incidence, as well as lack of systematic evaluation on the effect of PPIA on children surgeries. Although there was relevant Meta analysis in foreign countries, the quality of 9 articles in the literature was B grade, only the preoperative and anesthetic induced anxiety of children and their families were analyzed [6]. The paper aims to identify the impact of PPIA on children's perioperative effect through Meta-analysis, to overcome anesthesia induction difficulties and to offer evidence for the improvement of poor postoperative prognosis for the children.

\section{Objects}

\subsection{Literature Inclusion and Exclusion Standard}

\subsubsection{Literature Inclusion Standard}

Type of Study: The study involves a randomized controlled trial (RCT) of the effects of the anesthesia-induced intervention under the company of the family member.

\subsubsection{Research Object}

Inclusion standard: children featured with: 1) Aged between 1 to 12; 2) ASA I-II of American Society of Anesthesia Association, excluding severe liver and kidney dysfunction, congenital diseases, chronic diseases, and mental illness; 3) Elective surgery of general anesthesia; 4) Smooth anesthesia and operation. Parents: 1) Being informed, consented, and willing to participate; 2) With communication ability and free of mental illness.

\subsubsection{Interventions Included in the Literature}

Intervention group: routine anesthesia induction was performed on the day of operation and parents were present. Control group: routine anesthesia induction, accompanied by non-parents. 


\subsubsection{Exclusion Criteria}

The original literature type is case report and review; the original study does not describe the above results in detail; based on the original research, the secondary analysis literature is based on meta-analysis or systematic evaluation.

\subsubsection{Outcome Indicators}

1) Anxiety of sick children: Hamilton Anxiety Scale (HAS) was adopted in 9 papers [7]-[15] and Social Anxiety Scale for Children in Chinese (CSAS-C) in was applied in 1 paper [16]; 2) Delirium: Pediatric Anesthesia Emergence Delirium (PAED) [8] [10] [14] [17] [18]; 3) Anxiety of family members: State Trait Anxiety Inventory (STAI) used in 3 papers [9] [17] [19], and Sedation-Agitation Scale for adults (SAS) was applied in 1paper [20]; 4) Anesthesia cooperation for anesthesia: 4 papers [13] [14] [17] [19] adopted Induction Compliance Checklist (ICC); 1 paper [21] applied Concluding Emotion Method Scale (CEMS). 5) Pain: 1 paper by Face Pain Scale-Revised (FPS-R) [12]; another paper by Children's Hospital Eastern Ontario Pain Scale (m-CHEOPS) [16]; a scale of Face, Legs, Activity, Cry, and Consolability (FLACC) was used 1 paper [21].

\section{Methods}

\subsection{Searching Strategy}

The data was collected by searching the Chinese and English paper on the basis of the related academic dissertation and conference paper in Cochrane library, PubMed, Medline, Embase, ScienceDirect, SpringerLink, China Biomedical, CNKI, Wanfang, Weipu and other databases. The document search was created from each database until July 31, 2018. The search terms were adjusted according to the specific databases and the keywords were narrowed down based on the topic, abstracts, keywords and subject words used. The Chinese keywords were sick children/children/pediatric anesthesia/sick children' surgery, anesthesia induction/anesthesia, family member's accompany/parental presence, etc. And the English keywords were child undergoing surgery/pediatric anesthesia/parental presence, parental/presence during induction of anesthesia, anesthesia induction.

\subsection{Quality Evaluation of the References}

The evaluation was completed by the researchers who have received EvidenceBased Nursing System training, with 2 researchers comment the references as Cochrane advised [22], when different opinions appear, the third researcher would join in and review it accordingly. It will be graded for a $\mathrm{A}$ if the standards were fully met, B for partially met, and C for completely failed, which will be excluded. Both A and B could be adopted.

\subsection{Data Extraction}

We collected the authors, ages, the size of sample, the interventions used in experimental groups and control groups, anesthesia methods, surgical stages, etc. 
from the data.

\subsection{Data Analysis and Methods}

The Meta-analysis was performed by RevMan5.3 software. The continuous variable data was processed with standardized mean difference $(S M D)$. Due to different measurement tools used. The relative risk RR was calculated by binary data and $95 \%$ of CI was counted via effect analysis. The $I^{2}$ value was computed by Cochrane Q test [22] to examine the heterogeneity differences studies; if there were no heterogeneity $\left(P<0.1, P^{2} \geq 50 \%\right)$, we would apply the fixed effect model; if the heterogeneity $(P<0.1, P \geq 50 \%)$ was vast, we would use the random effect model, and discuss the source in subgroups analysis.

\section{Results}

\subsection{General Situation of Inclusion in the Study}

A total of 3876 reference were retrieved, of which 367 passages were Chinese and 3509 were English. After screening 15 articles were selected and the specific steps were shown as in (Figure 1). Among them, the intervention groups were divided into three subgroups in 3 groups, namely, the drug intervention group, the PPIA group, and the drug + parent companion group, and the drug + parental accompany group while 4 papers [11] [13] [16] [18] separated the intervention group into 2 subgroups (including a group of drug intervention and a group of PPIA). To make the data clearer and to achieve a consistency between the interventions and outcome indicators, we splited it into two RCTs. Finally, the qualified RCT were be selected and included into the basic traits of articles as shown in (Table 1).

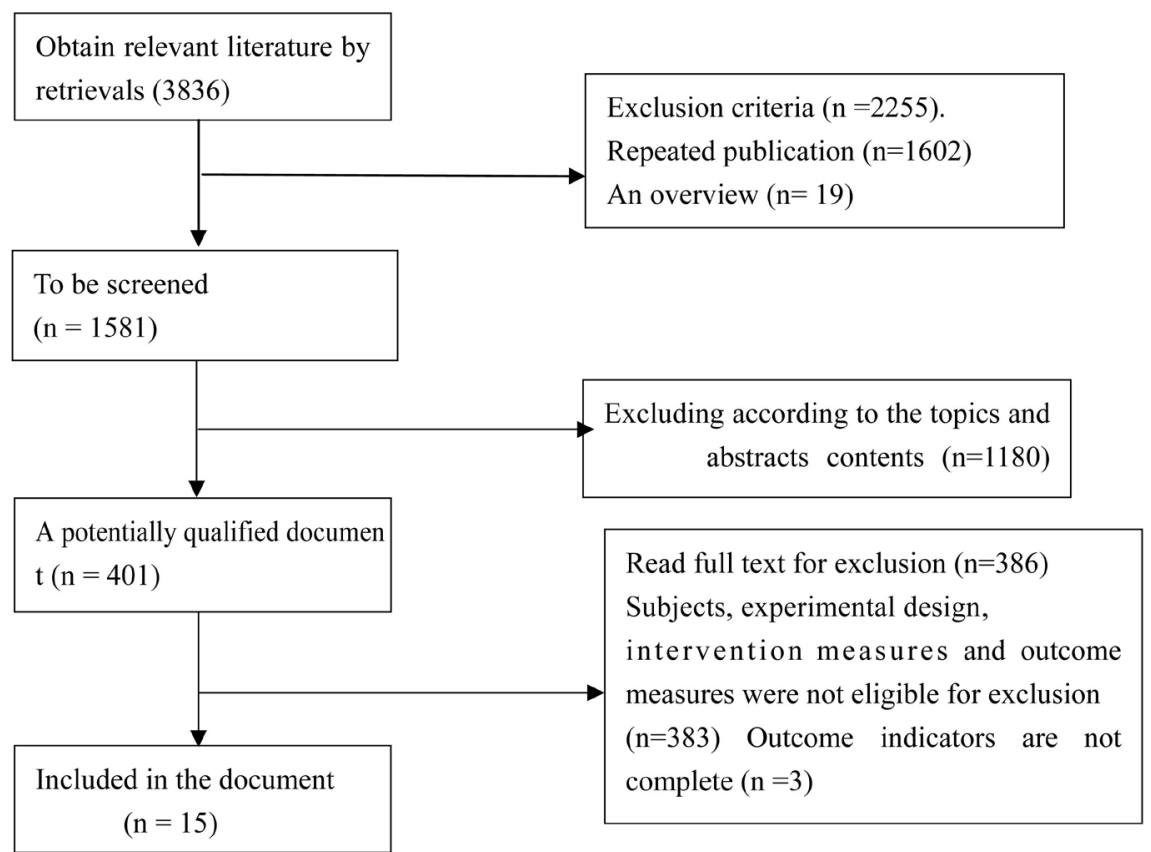

Figure 1. Flow chart of selected thesis. 
Table 1. Basic traits of selected thesis.

\begin{tabular}{|c|c|c|c|c|c|c|c|c|}
\hline \multirow{2}{*}{$\begin{array}{l}\text { Included } \\
\text { study }\end{array}$} & \multirow{2}{*}{ Nation } & \multirow{2}{*}{ Year } & \multirow{2}{*}{$\begin{array}{l}\text { Age of } \\
\text { children }\end{array}$} & \multicolumn{2}{|c|}{ Sample of size } & \multicolumn{2}{|c|}{ Interventions } & \multirow{2}{*}{$\begin{array}{l}\text { Outcome } \\
\text { index }\end{array}$} \\
\hline & & & & Control & Experiment & Control & Experiment & \\
\hline $\begin{array}{l}\text { Afsansh } \\
\text { et al. [7] }\end{array}$ & Iran & 2017 & $2-11$ & 48 & 48 & $\begin{array}{c}\text { No family company } \\
\text { with routine preoperative } \\
\text { nursing care }\end{array}$ & $\begin{array}{c}\text { Propaganda plus on the } \\
\text { day before operation + PPIA }\end{array}$ & $\mathrm{a}(\mathrm{T} 0-\mathrm{T} 2)$ \\
\hline $\begin{array}{l}\text { Kristen } \\
\text { et al. [17] }\end{array}$ & Canada & 2015 & $2-10$ & 44 & 49 & $\begin{array}{c}\text { No family company } \\
\text { with routine preoperative } \\
\text { nursing care }\end{array}$ & $\begin{array}{l}\text { Propaganda on the day } \\
\text { before operation + PPIA }\end{array}$ & $\begin{array}{l}\mathrm{b}(\mathrm{T} 1-\mathrm{T} 3) \mathrm{d} \\
\mathrm{e}(\mathrm{T} 3) \mathrm{c}\end{array}$ \\
\hline $\begin{array}{c}\text { Zeev } \\
\text { et al. [8] }\end{array}$ & $\begin{array}{l}\text { United } \\
\text { States }\end{array}$ & 2007 & $2-10$ & 99 & 94 & $\begin{array}{c}\text { No family company } \\
\text { with routine preoperative } \\
\text { nursing care }\end{array}$ & $\begin{array}{l}\text { Propaganda plus on the day } \\
\text { before operation + PPIA }\end{array}$ & $\begin{array}{l}\mathrm{a}(\mathrm{T} 1-\mathrm{T} 2) \\
\mathrm{e}(\mathrm{T} 1-\mathrm{T} 3)\end{array}$ \\
\hline $\begin{array}{l}\text { Arai } \\
\text { et al. }[18]\end{array}$ & Japan & 2007 & $1-3$ & 19 & 19 & $\begin{array}{c}\text { No family company } \\
\text { with routine preoperative } \\
\text { nursing care }\end{array}$ & $\begin{array}{l}\text { Propaganda on the day } \\
\text { before operation + PPIA }\end{array}$ & e (T3) \\
\hline $\begin{array}{c}\text { Kristi } \\
\text { et al. }[16]\end{array}$ & Canada & 2010 & $3-6$ & 30 & 31 & $\begin{array}{c}\text { No family company } \\
\text { with routine preoperative } \\
\text { nursing care }\end{array}$ & $\begin{array}{l}\text { Propaganda on the day } \\
\text { before operation + PPIA }\end{array}$ & a (T2 - T3) \\
\hline $\operatorname{Li}[9]$ & $\begin{array}{l}\text { Hong } \\
\text { Kong, } \\
\text { China }\end{array}$ & 2007 & $7-12$ & 106 & 97 & $\begin{array}{l}\text { No family company with } \\
\text { routine preoperative nursing } \\
\text { care }\end{array}$ & $\begin{array}{l}\text { Propaganda } 1 \text { - } 2 \text { weeks } \\
\text { before operation }+ \text { PPIA }\end{array}$ & $\begin{array}{c}\mathrm{a}(\mathrm{T} 1-\mathrm{T} 3) \mathrm{b} \\
(\mathrm{T} 1-\mathrm{T} 3) \mathrm{d}\end{array}$ \\
\hline $\begin{array}{l}\text { Farid } \\
\text { et al. }[10]\end{array}$ & Iran & 2011 & $2-7$ & 40 & 41 & $\begin{array}{c}\text { No family company } \\
\text { with routine preoperative } \\
\text { nursing care }\end{array}$ & $\begin{array}{l}\text { Propaganda on the day } \\
\text { before operation + PPIA }\end{array}$ & $\mathrm{e}$ \\
\hline $\begin{array}{l}\text { Spaffor } \\
\text { et al. }[21]\end{array}$ & Canada & 2002 & $5-12$ & 30 & 30 & $\begin{array}{c}\text { No family company } \\
\text { with routine preoperative } \\
\text { nursing care }\end{array}$ & $\begin{array}{c}\text { Propaganda one week } \\
\text { before operation + PPIA }\end{array}$ & c \\
\hline $\begin{array}{l}\text { Kain } \\
\text { et al. }[11]\end{array}$ & $\begin{array}{l}\text { United } \\
\text { States }\end{array}$ & 1998 & $2-8$ & 29 & 26 & $\begin{array}{c}\text { No family company } \\
\text { with routine preoperative } \\
\text { nursing care }\end{array}$ & $\begin{array}{c}\text { Propaganda three days before } \\
\text { operation + PPIA }\end{array}$ & $\mathrm{a}, \mathrm{d}(\mathrm{T} 1-\mathrm{T} 3)$ \\
\hline $\begin{array}{c}\text { Zeev } \\
\text { et al. [20] }\end{array}$ & $\begin{array}{l}\text { United } \\
\text { States }\end{array}$ & 1996 & $1-6$ & 41 & 41 & $\begin{array}{c}\text { No family company } \\
\text { with routine preoperative } \\
\text { nursing care }\end{array}$ & $\begin{array}{l}\text { Propaganda one week } \\
\text { before operation + PPIA }\end{array}$ & $\mathrm{a}, \mathrm{b}(\mathrm{T} 1-\mathrm{T} 2)$ \\
\hline $\begin{array}{l}\text { W. J. Huang } \\
\text { et al. [19] }\end{array}$ & China & 2017 & $6-11$ & 48 & 48 & $\begin{array}{c}\text { No family company } \\
\text { with routine preoperative } \\
\text { nursing care }\end{array}$ & $\begin{array}{l}\text { Propaganda on the day } \\
\text { before operation + FCC }\end{array}$ & $\begin{array}{l}\mathrm{a}(\mathrm{T} 0-\mathrm{T} 1) \mathrm{b} \\
(\mathrm{T} 0-\mathrm{T} 1) \mathrm{d} c\end{array}$ \\
\hline $\begin{array}{l}\text { L. F. Wang } \\
\text { et al. [12] }\end{array}$ & China & 2017 & $1-12$ & 34 & 34 & $\begin{array}{c}\text { No family company } \\
\text { with routine preoperative } \\
\text { nursing care }\end{array}$ & $\begin{array}{l}\text { Propaganda one week } \\
\text { before operation + PPIA }\end{array}$ & $\mathrm{a}(\mathrm{T} 1-\mathrm{T} 2)$ \\
\hline $\begin{array}{l}\text { J. F. Lou } \\
\text { et al. [13] }\end{array}$ & China & 2013 & $3-5$ & 20 & 20 & $\begin{array}{c}\text { No family company } \\
\text { with routine preoperative } \\
\text { nursing care }\end{array}$ & $\begin{array}{c}\text { Propaganda before } \\
\text { operation + PPIA + Games }\end{array}$ & $\begin{array}{c}\text { a (T0 - T3) } \\
\text { d (T0 - T3) } \\
\text { e (T3) c }\end{array}$ \\
\hline $\begin{array}{l}\text { G. Y. Zhang } \\
\text { et al. [14] }\end{array}$ & China & 2012 & $3-11$ & 52 & 52 & $\begin{array}{c}\text { No family company } \\
\text { with routine preoperative } \\
\text { nursing care }\end{array}$ & $\begin{array}{l}\text { Propaganda on the day } \\
\text { before operation + PPIA }\end{array}$ & $\mathrm{a}(\mathrm{T} 1-\mathrm{T} 4) \mathrm{d}$ e $\mathrm{c}$ \\
\hline Q.Xu [15] & China & 2011 & $2-12$ & 60 & 60 & $\begin{array}{c}\text { No family company } \\
\text { with routine preoperative } \\
\text { nursing care }\end{array}$ & $\begin{array}{l}\text { Propaganda on the day } \\
\text { before operation + PPIA }\end{array}$ & $\mathrm{a}$ \\
\hline
\end{tabular}

a. Children's anxiety level (mYPAS), (CSASC), and (STAI); b. The anxiety level of parents (STAI) and (SAS); c. Operative pain of children; d. Surgical cooperation ICC; e. Incidence of agitation PAED. T1 refers to preoperation, T2 refers to the anesthesia induction period, T3 refers to the period of recovery, and T4 refers to $6 \mathrm{~h}$ after the operation. Family-Centered Nursing Care Under Parent-Present Induction of Anesthesia (PPIA) is (FCC). 


\subsection{Methodological Quality of the Selected Papers}

In the 15 pieces of selected documents, 4 of documents [8] [13] [17] [18] were graded as A; 11 of documents [7] [9] [10] [11] [12] [14] [15] [16] [19] [20] [21] were evaluated as $\mathrm{B}$. The specific evaluation indicators and results are shown as in (Table 2).

\subsection{Results of Meta-Analysis}

\subsubsection{Preoperative Anxiety of Sick Children}

9 articles [7] [8] [9] [12] [13] [14] [15] [16] [19] have reviewed the effect of PPIA on the preoperative anxiety for children and the results indicated $\left(F^{2}=92 \%, P<\right.$ 0.001 ) that a heterogeneity using the adopted randomized efficacy model and combined effect model were statistically significant $[S M D=-0.85,95 \% C I$ $(-1.32,-0.38), P<0.05]$, as shown in (Figure 2). We made a subgroup analysis on the heterogeneity and categorized them into group A by age and group B by foreign or domestic researches. In 3 papers [13] [16] [20], the included objects were sick children from 1 to 6 years old, classified as group A1 and another group of sick children aged from 2 to 5 was classified as group A2 in 2 thesis, the heterogeneity test results of A1 and A2 in the subgroups were $(P=84 \%, P<$ $0.001)$ and $\left(P^{2}=93 \%, P<0.001\right)$ respectively, both with a large heterogeneity and were processed with randomized efficacy model with a statistical significance, A1 [ $S M D=-0.79,95 \% C I(-1.03,-0.54), P<0.01]$ and A2 [SMD $=-0.72,95 \%$ $C I(-0.92,-0.53), P<0.01]$. In the analysis of B subgroups, 6 assays [9] [12] [13] [14] [15] [19] were domestic studies, (marked as group B1) and another 3 papers [7] [16] [20] were foreign studies, named as group B2. The heterogeneity test results of the group B1 and group B2 $\left(I^{2}=93 \%, P<0.001, I^{2}=81 \%, P<0.001\right)$ both showed a large heterogeneity and were processed with randomized efficacy model with a statistical significance with, B1 [SMD $=-0.94,95 \% C I(-1.60$, $-0.29), P<0.01]$ and B2 [SMD $=-0.79,95 \% C I(-0.91,-0.19), P<0.01]$.

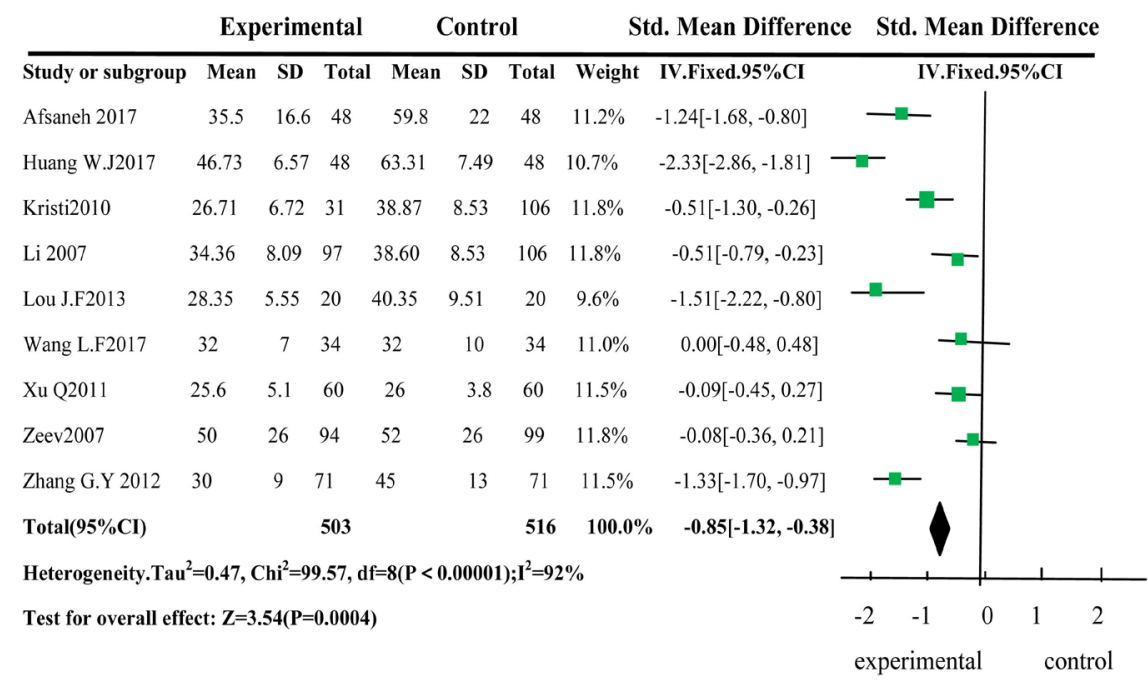

Figure 2. Preoperative anxiety index of children. 
Table 2. Methodological quality evaluation of study inclusion

\begin{tabular}{|c|c|c|c|c|c|c|c|}
\hline Studies included & $\begin{array}{c}\text { Random } \\
\text { sequence } \\
\text { generation }\end{array}$ & $\begin{array}{l}\text { Blinding of } \\
\text { participants }\end{array}$ & $\begin{array}{l}\text { Blinding of } \\
\text { outcome } \\
\text { assessment }\end{array}$ & $\begin{array}{l}\text { Incomplete } \\
\text { outcome data }\end{array}$ & $\begin{array}{l}\text { Selective } \\
\text { reporting }\end{array}$ & $\begin{array}{l}\text { Other } \\
\text { bias }\end{array}$ & $\begin{array}{l}\text { Quality } \\
\text { grade }\end{array}$ \\
\hline Afsansh et al. [7] & High & Unclear & Low & Low & Low & Low & B \\
\hline Kristen et al. [17] & Low & Low & Low & Low & Low & Low & A \\
\hline Zeev et al. [8] & Low & Low & Low & Low & Low & Low & A \\
\hline Arai et al. [18] & Low & Low & Low & Low & Low & Low & A \\
\hline Kristi et al. [16] & Low & unclear & Low & Low & Low & Low & B \\
\hline Li et al. [9] & High & Low & Low & Low & Low & Low & B \\
\hline Farid et al. [10] & Low & unclear & Low & Low & Low & Low & B \\
\hline Spafford et al. [21] & Low & unclear & Low & Low & Low & Low & B \\
\hline Kain et al. [11] & Low & unclear & High & Low & Low & Low & B \\
\hline Zeev et al. [20] & High & unclear & unclear & Low & Low & Low & B \\
\hline W. J. Huang [19] & High & unclear & Low & Low & Low & Low & B \\
\hline L. F. Wang et al. [12] & High & unclear & unclear & Low & Low & Low & B \\
\hline J. H. Lou [13] & Low & Low & Low & Low & Low & Low & A \\
\hline G. Y. Zhang [14] & Low & high & unclear & Low & Low & Low & B \\
\hline Q. Xu et al. [15] & High & Low & unclear & Low & Low & Low & B \\
\hline
\end{tabular}

\subsubsection{Agitation in Anesthesia Induction and Recovery Period}

In the included articles, 6 articles [10] [13] [14] [16] [18] [20] offered an assessment on the effect of PPIA upon the incidence of agitation in children. To be specific, 2 articles [14] [20] are the agitation indicators during anesthesia induction and the results showed $\left(P^{2}=1 \%, P=0.33\right)$ no heterogeneity, therefore the fixed efficacy model was used. The agitation incidence of children during anesthesia induction in PPIA group was lower compared to the control group [ $R R=$ $0.61,95 \% \mathrm{CI}(0.43,0.88), P<0.001]$ with a statistical significance. On the contrary, 4 articles [10] [13] [16] [18] showed the agitation index during the recovery period, from which the results indicating no heterogeneity applied by fixed efficacy model. Moreover, the children in PPIA group showed a lower agitation incidence during the recovery period $[R R=0.74,95 \% C I(0.55,0.98), P<0.05]$ in comparison with the control group with a statistical significance as shown in (Figure 3).

\subsubsection{Anesthesia Cooperation}

5 articles [9] [11] [13] [14] [19] reviewed the effect of PPIA on the children' cooperation in anesthesia and the results revealed $\left(F^{2}=87 \%, P<0.001\right)$ that a presence of heterogeneity with a statistical significance using the randomized effect model $[S M D=41.08,95 \% C I(-41.64,-0.52), P<0.01]$, the anesthetic coordination of children in PPIA group was significantly higher than that in control group, as shown in (Figure 4). 


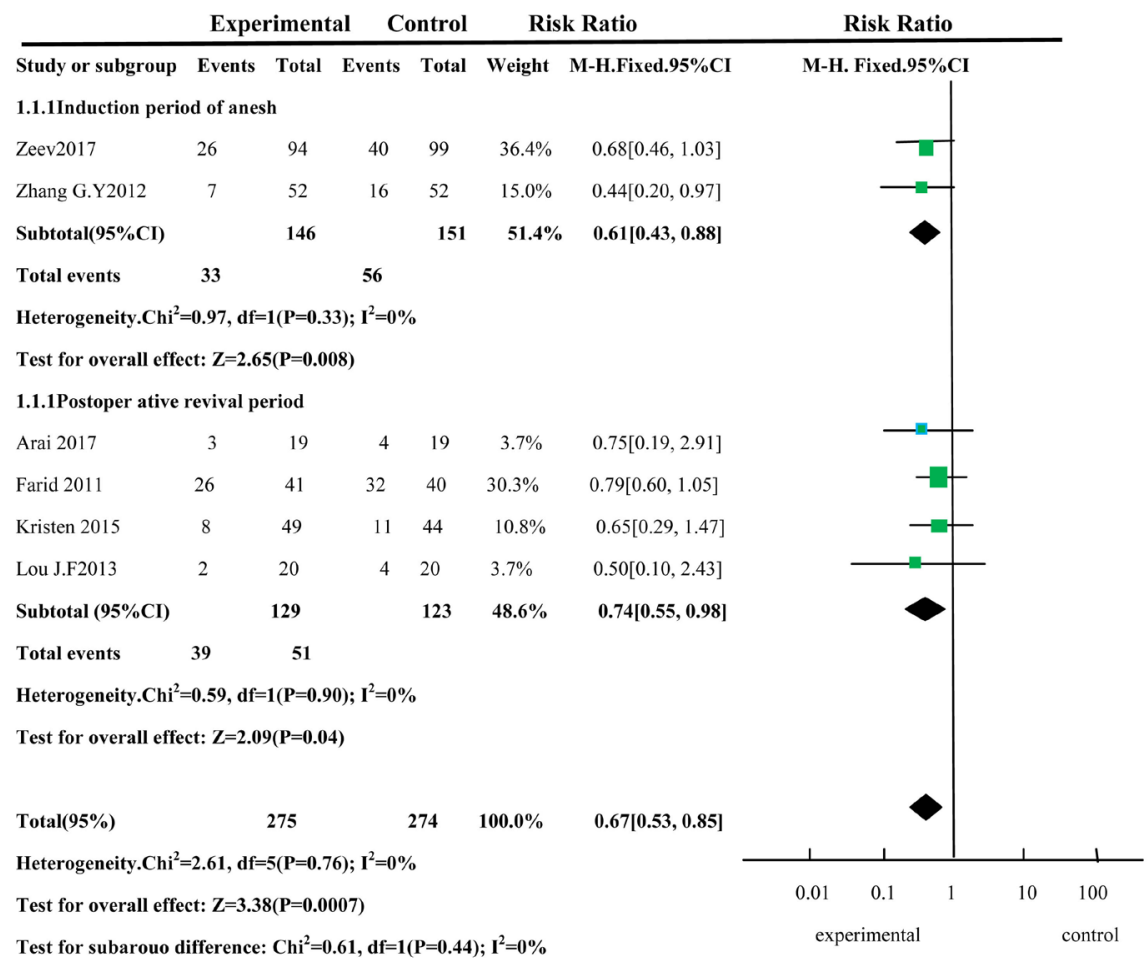

Figure 3. Children's agitation index during anesthesia induction and recovery.

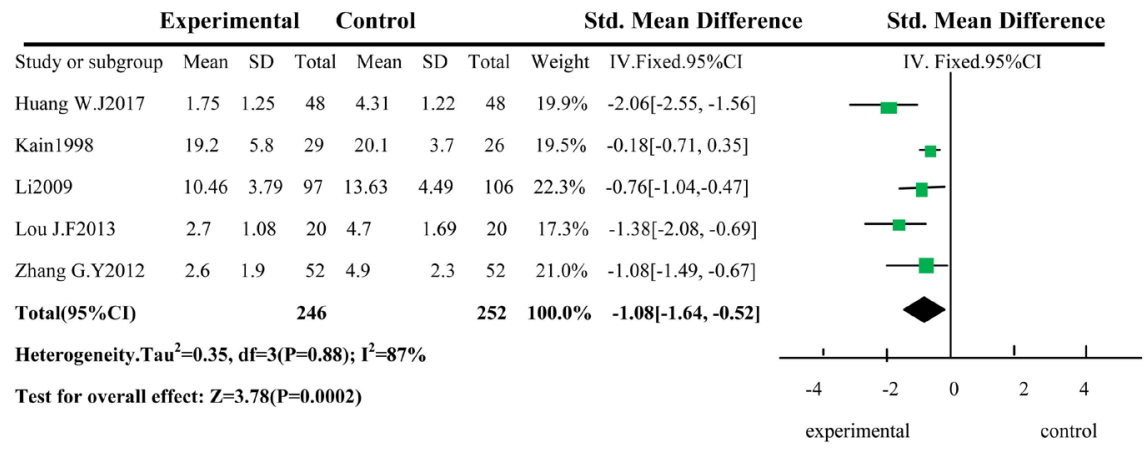

Figure 4. Children's cooperation index during anesthesia.

\subsubsection{Preoperative Anxiety of Parents}

4 references [8] [9] [11] [19] commented on the effect of PPIA on anxiety level of parents before surgery and the heterogeneity tests showed $\left(I^{2}=0 \%, P<0.001\right)$ no heterogeneity, which was thus dealt with the fixed effect model The preoperative anxiety degree of the parents in group PPIA was lower than that of the control group $[S M D=0.37,95 \% C I(0.19,0.55), P<0.01]$ and the difference was statistically different, as shown in (Figure 5).

\subsubsection{Pain during Recovery Period}

In the included documents, 3 pieces of papers [13] [17] [21] covered the evaluation of the effect of PPIA on the level of pain of children during the recovery stage. The results indicated $\left(P^{2}=0 \%, P=0.93\right)$ no heterogeneity applying the fixed effect model. Postoperative pain in PPIA group was significantly lower 
than that in control group. [ $S M D=-0.38,95 \%$ CI $(-0.66,-0.09), P<0.05]$ and the difference was statistically significant, as shown in (Figure 6).

\subsection{Meta-Analysis Results Collection}

The Meta-analysis covered 6 outcome indicators in total, and we scored 1 to 2 for each according to the importance with a total point of 10 . The points $\geq 3$ stood for a good intervention performance of PPIA towards the operation. $87 \%$ RCT studies suggested that PPIA imposed a good intervention effect on operation and it's applicable clinically (Table 3, Figure 7).

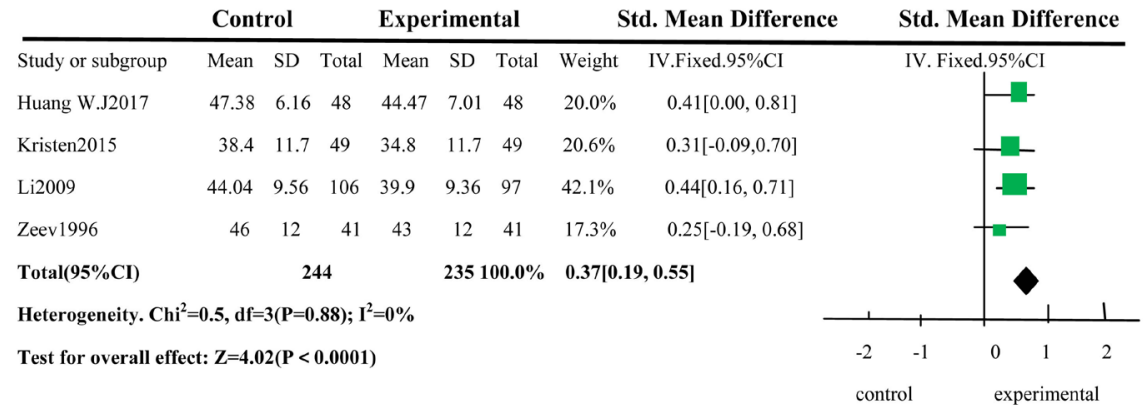

Figure 5. Parents' preoperative anxiety index.

Table 3. Outcome index assignment table.

\begin{tabular}{|c|c|c|c|c|c|c|c|}
\hline Included study & $\begin{array}{c}\text { Children' } \\
\text { preoperative } \\
\text { anxiety (2) }\end{array}$ & $\begin{array}{c}\text { Parent's } \\
\text { preoperative } \\
\text { anxiety (1) }\end{array}$ & $\begin{array}{l}\text { Agitation during } \\
\text { anesthesia } \\
\text { induction (1) }\end{array}$ & $\begin{array}{c}\text { Agitation } \\
\text { during recovery } \\
\text { period(2) }\end{array}$ & $\begin{array}{l}\text { Anesthesia } \\
\text { cooperation } \\
\text { (2) }\end{array}$ & $\begin{array}{c}\text { Postoperative } \\
\text { pain (2) }\end{array}$ & $\begin{array}{l}\text { Total scores } \\
\text { (10 points) }\end{array}$ \\
\hline Afsansh et al. [7] & 2 & 1 & 0 & 0 & 0 & 0 & 3 \\
\hline Kristen et al. [17] & 0 & 1 & 0 & 2 & 2 & 2 & 7 \\
\hline Zeev et al. [8] & 2 & 0 & 1 & 2 & 0 & 0 & 5 \\
\hline Arai et al. [18] & 1 & 0 & 0 & 2 & 0 & 0 & 3 \\
\hline Farid et al. [16] & 2 & 0 & 0 & 0 & 0 & 0 & 2 \\
\hline $\operatorname{Li}[9]$ & 2 & 1 & 0 & 2 & 0 & 2 & 7 \\
\hline Farid et al. [10] & 2 & 0 & 0 & 2 & 0 & 0 & 4 \\
\hline Spaffor et al. [21] & 2 & 0 & 0 & 0 & 2 & 0 & 4 \\
\hline Kain et al. [11] & 2 & 1 & 0 & 2 & 0 & 0 & 5 \\
\hline Zeev et al. [20] & 2 & 1 & 0 & 2 & 0 & 0 & 5 \\
\hline W. J. Huuang. et al. [19] & 2 & 1 & 0 & 0 & 2 & 0 & 5 \\
\hline L. F Wang et al. [12] & 2 & 0 & 0 & 0 & 0 & 0 & 2 \\
\hline J. F. Lou et al. [13] & 2 & 0 & 0 & 2 & 2 & 2 & 8 \\
\hline G. Y. Zhang. et al. [14] & 2 & 0 & 0 & 2 & 2 & 0 & 6 \\
\hline Q. Xu et al. [15] & 2 & 0 & 0 & 0 & 2 & 0 & 4 \\
\hline
\end{tabular}




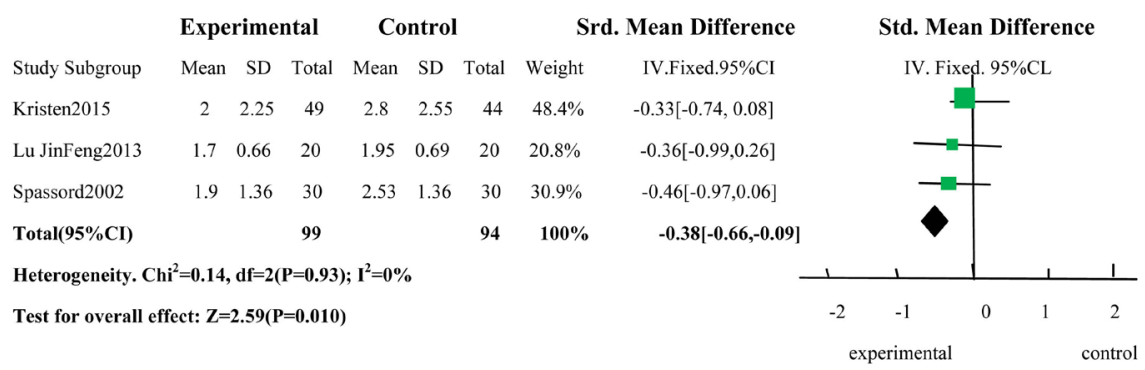

Figure 6. Pain index of children during recovery.

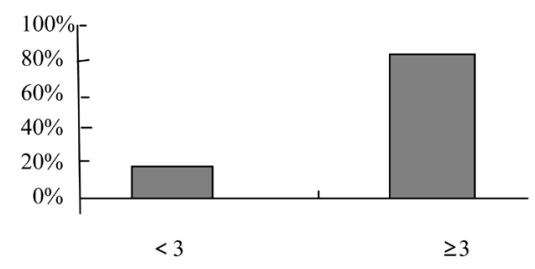

Figure 7. Outcome total score column chart.

\subsection{Sensitivity Analysis}

Sensitivity analysis of more than 3 outcome indexes was carried out, and 9 cases [7] [8] [9] [12] [13] [14] [15] [16] [19] of children's preoperative anxiety were analyzed. Large sample group [9] was excluded. In the study, the data onto the remaining 8 pre-operative anxiety indexes were analyzed again after removing the lowest sample size of Lou Jinfeng [13], and the results of both analyses were not changed. In the study of children's recovery arousal index, the Kristen [17] study with the largest sample size or the Aila [18] study with the smallest sample size was deleted, and the other three indexes were reanalyzed and analyzed twice. Results there was no change. In analysing the anesthesia cooperation thinking data of five children [9] [11] [13] [14] [19], the Li [9] study with a large sample was deleted, or the minimum sample size of [13] was deleted, and the remaining three indicators were reanalyzed, the results of the two analyses remain unchanged. In four [9] [17] [19] [20] parents' preoperative anxiety indicators included in the study, sample size was removed. The maximum study of $\mathrm{Li}$ [9], or the study of Zeev [20], removed the minimum sample number, reanalyzed the remaining three indexes, and did not change in two analyses. All the above results were treated by sensitivity analysis, the results showed no change, indicating that the results were stable.

\section{Discussion}

\subsection{Methodological Quality of Studies Including}

15 articles have been included in this study, with a medium quality, which could be further improved. We compared the baseline levels of all subjects and found that the obtained differences were not statistically significant $(P>0.05)$. Among them, 9 pieces of them [7] [10] [11] [12] [14] [16] [19] [20] [21] failed to report the latent distribution; 5 papers [11] [12] [14] [15] [20] didn't explain if the 
blind method was applied to the measurer; apart from that 5 papers [7] [12] [15] [18] [20] using randomized control methods lack an elaboration on the random sequences' generation, and thereby a high risk of bias was considered; furthermore, 6 references [8] [9] [10] [11] [16] [17] involved an intentional analysis on the number of people missing the follow-up. Although some of the articles failed to report the loss of data, the data was completed.

\subsection{Promotion Effect of PPIA on the Children's Surgical Intervention Performance}

The results of the Meta-analysis indicated that the preoperative anxiety level of the children and their parents in PPIA group was lower than that of the control group and the anesthesia cooperation degree was higher. Children who stay in an unfamiliar environment, especially during the waiting and the beginning of anesthesia induction tend to feel excessively nervous and upset; along with their limited language and thinking capability, the operation response may be hindered. Studies [23] have found that on one hand, the parents play a vital role in children's stress and anxiety regulation in a surgery since it was easy for parents to pass the pressure to their children indirectly. On the other hand, the anxiety level of the parents would fall down as their child's anxiety relieved, which was consistent with the Meta-analysis result in which the preoperative anxiety of the parents in PPIA group showed an alleviation versus that of the control group. The companion and comforting from family members gave the children a sense of trust and satisfaction so that they cry less and feel more relieved, which will contribute to a better operation performance.

Studies [1] [7] showed that the anxiety level of children below 6 years old towards the surgery was higher than that of the children aged over 6; therefore, for results with higher heterogeneity, we divided them into two subgroups by age in subgroup analysis and then classified them into another 2 subgroups, namely the domestic and foreign groups by cultural differences with heterogeneity; the conclusion could be drawn that the regional race and the original diseases type may be the reason why the distinction formed. Meanwhile, there was a large heterogeneity in the heterogeneity tests as shown in 5 studies of anesthesia cooperation index [7] [8] [12] [13] [19] with no obvious clinical difference, hence, no subgroup analysis was covered. The heterogeneity may be caused by the difference in the types of primary diseases and the way of general anesthesia. The difference in children's anxiety levels during anesthesia induction between the two groups in the L. F. Wang's research [12] was not statistically significant, but she pointed out that as the advancement of the medical and anesthesia technology, the anxiety levels of the sick children in the perioperative period could have been alleviated by the improved service of nursing staff as well as, the strengthened care and comfort, however, whether it can be implemented relies mostly on the situation of the hospital and the sick children due to the heavy workload.

In the Meta-analysis, it can be observed that the incidence of children agitation during anesthesia induction and recovery was lower in the group PPIA than 
that of the control group. Because of the effect of trauma and anesthetic, the normal physiological function of the children was changed, along with the immature physiological and psychological development as well as the poor endurance of the children, it would easily lead to stress reaction and the impacted anesthesia effect, as a result, agitation will occur so that the adverse consequence such as the emergency agitation (EA) and a series of reactions like the vital signs fluctuation and falling ducts even serious complications may arise. Studies have confirmed that postoperative agitation is closely related to preoperative anxiety [7]. Children's consciousness is not fully restored in recovery period and they could not get rid of the adverse consequences immediately due to anxiety and fear. Under this circumstance, the incidence of agitation was higher than that of the PPIA group. At the same time, the postoperative pain would increase the agitation rate, which was interrelated and consistent with the results of the Meta analysis.

\subsection{Limitation}

Since only Chinese and English randomized controlled trials were selected, and the number of references on each index was low, we only launched a funnel plot test on the preoperative anxiety index of the PPIA group and the control group in 9 papers [7] [9] [12] [13] [14] [15] [16] [19] [20]. The results might be asymmetric and the risk of publication bias was considered. In addition, the included studies used different scales, different countries and regions of study, and different doses of anesthesia used by children during surgery, which may be the cause of heterogeneity. Although the overseas study of PPIA has been mature, RCT studies are relatively less which mainly focuses on prospective and qualitative researches [24]. In order to explore the factors affecting PPIA's self-management ability and the anxiety of family members and children during perioperative period, it is worth noting that some scholars [25] explore the anesthetic medication and suffering from the objective angle of anesthesiologists and the degree of cooperation. While we paid a few attentions to the RCT, therefore, the future research may as well be done from the point of the degree of children' coordination, anesthetic dosage, as well as the various anxiety level of different age groups.

\section{Conflicts of Interest}

The authors declare no conflicts of interest regarding the publication of this paper.

\section{References}

[1] Hatice, K., Ozdogan, A., Sibel Cetinalp, A., et al. (2017) The Effects of Maternal Presence during Anesthesia Induction on Salivary Cortisol Levels in Children Undergoing Tonsillectomy and/or Adenoidectomy. Journal of Clinical Anesthesia, 39, 64-66. https://doi.org/10.1016/j.jclinane.2017.03.001

[2] Dionigi, A. and Gremigni, P. (2017) A Combined Intervention of Art Therapy and Clown Visits to Reduce Preoperative Anxiety in Children. Journal of Clinical Nurs- 
ing, 6, 632-640. https://doi.org/10.1111/jocn.13578

[3] Ma. Y.J., Gou, M.J., Guo, H.L., et al. (2009) Study on the Effect of Parental Accompanying Pediatric Anesthesia Induction. Chinese Journal of Nursing, 9, 845-847.

[4] Kruger, P. and Rosen, D. (2016) Parental Presence at Induction of Anesthesia Is Feasible with Minimal Preparation and Resources. Canadian Journal of Anaesthesia, 7, 1-2. https://doi.org/10.1007/s12630-016-0707-x

[5] Rastiemadabadi, R., Naboureh, A., Nasiri, M., et al. (2017) The Effects of Preanesthetic Parental Presence on Preoperative Anxiety of Children and their Parents: A Randomized Clinical Trial Study in Iran. Iranian Journal of Nursing Midwifery Research, 1, 72-77.

[6] Erhaze, E.K., Dowling, M. and Devane, D. (2016) Parental Presence at Anaesthesia Induction: A Systematic Review. International Journal of Nursing Practice, 22, 397-407. https://doi.org/10.1111/ijn.12449

[7] Sadeghi, A., et al. (2017) Impact of Parental Presence during Induction of Anesthesia on Anxiety Level among Pediatric Patients and Their Parents: A Randomized Clinical Trial. Neuropsychiatric Disease and Treatment, 12, 3237-3241.

https://doi.org/10.2147/NDT.S119208

[8] Kain, Z.N., et al. (2007) Family-Centered Preparation for Surgery Improves Perioperative Outcomes in Children. Anesthesiology, 10, 65-74.

https://doi.org/10.1097/00000542-200701000-00013

[9] Li, H.C., Lopez, V. and Lee, T.L. (2007) Psychoeducational Preparation of Children for Surgery: The Importance of Parental Involvement. Patient Education and Counseling, 65, 34-41. https://doi.org/10.1016/j.pec.2006.04.009

[10] Zand, F., Allahyary, E. and Hamidi, A.R. (2011) Postoperative Agitation in Preschool Children Following Emergence from Sevoflurane or Halothane Anesthesia: A Randomized Study on the Forestalling Effect of Midazolam Premedication versus Parental Presence at Induction of Anesthesia. Acta Anaesthesiologica Taiwanica, 3, 96-99. https://doi.org/10.1016/j.aat.2011.09.001

[11] Kain, Z.N., Mayes, L.C., Wang, S.M., et al. (1998) Parental Presence during Induction Anesthesia versus Sedative Premedication: Which Intervention Is More Effective? Anesthesiology, 89, 1147-1156. https://doi.org/10.1097/00000542-199811000-00015

[12] Wang, L.F., Xu, Y.J., Zhang. X.Y. and Li, X. (2017) The Effect Evaluation of the Anaesthesia in the Children with the Accompanying Anaesthesia in the Parents. Chinese Clinician Magazine (Electronic Edition), 6, 1049-1051.

[13] Lou, J.F. (2012) Imidazole and Parents Escort Effect on the Restlessness of the Children after Total Intravenous Anesthesia in the Wake of the Awakening Period. Doctoral Thesis, Jilin University. http://cdmd.cnki.com.cn/Article/CDMD-10183-1013194150.htm

[14] Zhang, G.Y. (2012) Influence of Anesthesia Induction on Psychological Intervention of Children during Perioperative Period. Qilu Nursing Journal, 26, 8-10.

[15] Xu, Q. and Wu, P. (2011) The Influence of Parental Companionship on the Anxiety State of Children during Induction of Sevoflurane Anesthesia. Chinese Journal of Anesthesiology, 6, 674-676.

[16] Wright, K.D., Stewart, S.H. and Finley, G.A. (2010) When Are Parents Helpful? A Randomized Clinical Trial of the Efficacy of Parental Presence for Pediatric Anesthesia. Canadian Journal of Anesthesia, 8, 751-758.

https://doi.org/10.1007/s12630-010-9333-1 
[17] Kristen, M., et al. (2015) Preparing Parents to Be Present for Their Child's Anesthesia Induction. Anesthesia \& Analgesia, 4, 1001-1010.

[18] Arai, Y.-C.P., Ito, H., Kandatsu, N., et al. (2007) Parental Presence during Induction Enhances the Effect of Oral Midazolam on Emergence Behavior of Children Undergoing General Anesthesia. Acta Anaesthesiologica Scandinavica, 7, 858-861. https://doi.org/10.1111/j.1399-6576.2007.01339.x

[19] Huang, W.J. (2007) The Application of a Family-Centered Interactive Pre-Operative Visit in the Visit of the Children with Inguinal Hernia Surgery. Qingdao University's Thesis. http://nvsm.cnki.net/kns/brief/default_result.aspx

[20] Kain, Z.N., Linda, C., et al. (1996) Parental Presence during Induction of Anesthesia: A Randomized Controlled Trial. Anesthesiology, 5, 1060-1067.

https://doi.org/10.1097/00000542-199605000-00007

[21] Spafford, P.A., von Baeyer, C.L. and Hicks, C.L. (2002) Expected and Reported Pain in Children Undergoing Ear Piercing: A Randomized Trial of Preparation by Parents. Behaviour Research and Therapy, 40, 253-266. https://doi.org/10.1016/S0005-7967(01)00008-0

[22] Higgins, J.P. and Green, S. (2016) Cochrance Handbook for Systematic Reviews of Intervention Version 5.1.0 [EB/OL]. http://handbook.cochrane.org

[23] Liu, S.T., Gao, X.H., Lin, H.S. and Pei, Y. (2017) Influence of Parental Cozy Anesthesia Technology on the Compliance of Anesthesia Induction in Children. Chongqing Medicine, 27, 3776-3778.

[24] Babazade, R., Dogangun, B., Sutas-Bozkurt, P., et al. (2015) Association between Anxiety Level of Child with Parental and Patient Factors during Preoperative Anesthesia Visit. The Open Psychiatry Journal, 9, 11-16. https://doi.org/10.2174/1874354401509010011

[25] Vejzovic, V., Bramhagen, A.C., Idvall, E. and Wennick, A. (2015) Parents' Experiences When Their Child Is Undergoing an Elective Colonoscopy. Journal for Specialists in Pediatric Nursing, 2, 123-130. https://doi.org/10.1111/jspn.12109 